\title{
Quantitative and Qualitative Improving of Legumes Production Using Nuclear Techniques and Package of Technology with Mutation Induction
}

ISSN: 2637-7659

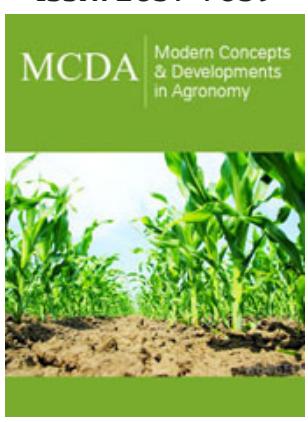

*Corresponding author: Dheya P Yousif, Agricultural Research Directorate, Ministry of Science and Technology, PO Box 765, Baghdad, Iraq

Submission: 悔June 07, 2019

Published: 侮June 17, 2019

Volume 4 - Issue 4

How to cite this article: Dheya P Y. Quantitative and Qualitative Improving of Legumes Production Using Nuclear Techniques and Package of Technology with Mutation Induction. Mod Concep Dev Agrono.4(4). MCDA.000593.2019. DOI: 10.31031/MCDA.2019.04.000593

Copyright@ Dheya P Yousif, This article is distributed under the terms of the Creative Commons Attribution 4.0 International License, which permits unrestricted use and redistribution provided that the original author and source are credited.

\section{Dheya P Yousif*}

Agricultural Research Directorate, Iraq

\section{Editorial}

Although Iraq is the centre of origin for several crops, its cultivation is still exposure for several constraints. The lack of breeding programs, cultivation of old cultivars, environmental stresses and poor field practices and management caused to decline the crop productivity. On the other hand, no or less attention for legumes crops, especially for breeding programs, cultivars development and germplasm availability. Winter legumes (Vicia faba L. and Vigna unguiculata) and summer legumes (Arachis hypogae L. and Vigna radiata L.) are the most important, short duration pulse legume crops. The four legumes crops present the main source of protein in staple food and diets due to its role in compensation the lack of expensive animal protein in Iraq. More than $30 \%$ of population severe of poverty, and sufficient protein is not available because of low income and an expensive price of animal protein. Important short duration pulse crop in Iraq presents the major source of diets as well as being used as an intercrop due to its drought tolerance and nitrogen-fixing soil fertilization. Unfortunately, the legumes crops sever of low yield potential and the urgent need is to broaden the genetic background of local breeding varieties. The local cultivars characterised with low yield potential and limited genetic base in addition to the established constraints, such as drought, salinity and susceptibility to various diseases.

However, mutation breeding program must be carried to break the yield potential barriers. Emphasis on broadening the genetic base of the crop by introducing an exotic germplasm and induced mutations for the target objectives to enhance an efficient and high out-yielding cultivars and developing field management under irrigated and rain-fed agriculture must be considered. Mutation induction, using gamma rays, revealed the most successions of creating useful genetic variability which serve deducing of an exceeded crop cultivation breeding program to this crop may be implemented to break the yield potential barriers, enhancing tolerant to environments stresses and increasing the efficiency of biological nitrogen $\mathrm{f} s$, enhancing tolerant to environmental stresses, increasing the efficiency of biological nitrogen fixation and possibility of better water productivity. Therefore, applying new technologies and nuclear techniques will contribute in sustaining legumes cropping, production ecosystems, assist farmers and small Salk holders to improve their incomes and secure good protein supply to their families.

The objectives are:

Develop and deduce new crop cultivars characterized with high yield potential and desired characteristics of short stature, determinate growth, earliness in flowering and enhance uniformity in pod maturity with favourable level of drought and salt tolerance and biotic stress.

a) Increasing efficiency of the biological nitrogen fixation.

b) Evaluation of the soil stresses on BNF efficiency.

c) Maximum exploitation for affected soils with drought and negligible inputs. 
d) Enhancing plant and soil system horizontally and vertically.

e) Application of ionizing radiation with tissue culture to increase the mutation frequency and provide a wide range of variability for selection.

f) Improve the production via the application of mutation and molecular marker assisted selection technique.

g) Improving the socioeconomic approaches throughout rehabilitation of farmer's livings and establishment.

h) Exploitation of the current crop genetic adaptability. i) Utilization of the methods recombination among all available breeding trends and germplasm exchange.

j) Utilization of the available expert philosophy in IAEA.

k) The ability to apply the program in multi-locations of the targeted area.

I) Measurement and estimates all reflected outputs on farmers and land establishment.

m) The capacity building for scientists, researchers, technicians and farmers. 